\title{
Fundamental Rights as the Cornerstone of Schengen
}

\author{
Tineke Strik \\ Member of the European Parliament \\ Professor of Citizenship and Migration Law, Centre for Migration Law, \\ Faculty of Law, Radboud University, Nijmegen, The Netherlands \\ tineke.strik@ru.nl
}

\begin{abstract}
Although the Schengen Border Code (SBC) explicitly obliges Member States to apply the Schengen rules in full compliance with the fundamental rights, Member States' adherence to this obligation can be questioned in light of recurrent and reliable reports about fundamental rights violations at the EU's external borders. This contribution will examine why, apart from the deficiencies in the SCHE-VAL mechanism, the current response towards fundamental rights violations at the border is ineffective. First, it will analyse the legal framework, including the implementing rules, to see if additional guidance is needed. Second, the enforcement mechanisms will be examined: how are violations being addressed at the national level, and how does the EU Commission perceive and fulfills its role regarding enforcement of compliance? As the Commission has often referred to the monitoring mechanism as proposed in the draft Screening Regulation, the contribution will examine to what extent this New Pact file will help to resolve the current impunity. Finally, the article will analyse the role of Frontex regarding human rights violations by Member States. What is their responsibility, how do they perform it, and who is enforcing compliance by Frontex?
\end{abstract}

\section{Keywords}

Schengen Borders Code - fundamental rights - Schengen Evaluation and Monitoring Mechanism - pushbacks - Screening Regulation - Frontex 


\section{Introduction}

Although the Schengen area is often marked as one of the biggest achievements of European integration, since its existence it has become clear that the essential safeguards of Schengen cannot be taken for granted. As already announced in its Communication on the Pact on Asylum and Migration, the Commission presented a Strategy on the future of Schengen, specifically focussing on ways to make the Schengen Borders Code (SBC) more effective and to improve the Schengen Evaluation and Monitoring Mechanism (SEMM). ${ }^{1}$ Most of the proposals in the current reform of the Schengen area relate to ways to restore the absence of internal border control and to safeguard free travel again. But the implementation gap concerning fundamental rights obligations deserves to be a prominent part of the reform process as well. Recurrent and consistent reports about fundamental rights violations at the external borders expose the need for a more effective mechanism to tackle and prevent those violations.

This contribution examines why the current response towards fundamental rights violations at the border is ineffective, and how compliance can be furthered. It will first analyse the legal framework, including the implementing rules, to see if new rules or more specific guidance is needed. Second, the enforcement mechanisms will be examined: how are violations being addressed at the national level, and how does the EU Commission fulfil its role as a Guardian of the Treaties? In this context, the article elaborates on the monitoring mechanism as proposed in the draft Screening Regulation. Will this help to resolve the current impunity? Subsequently, it analyses the role of Frontex regarding human rights violations by Member States and looks into the findings of the recent inquiries on the allegations of complicity of Frontex in pushbacks by the Member States. On the basis of this overview, I will elaborate on the most effective solution to enhance compliance with fundamental rights obligations at EU's borders: do we need new rules, new instruments or new enforcement mechanisms?

Reform Underway: The SBC and the SEMM

\subsection{A New Strategy for Schengen}

In June 2021, the Commission released a Communication on a 'strategy towards a fully functioning and resilient Schengen area', based on a broad

$1 \operatorname{COM}(2020) 609,23$ September 2020, para 4.4. $\operatorname{COM}(2021) 277,2$ June 2021. 
consultation with the Member States, the Parliament and other stakeholders. ${ }^{2}$ The Commission considers that reform is needed in three areas: the external border management, measures compensating for the absence of internal border controls (such as a visa and return policy, police cooperation and IT systems) and the governance part, which includes the SEMM, regulating the basis for assessing compliance with the Schengen rules. ${ }^{3}$ Regarding the external border management, the Commission announced a Communication with the Multiannual Strategic Policy, on the basis of Article 8 (1) Regulation 2019/1896, in close cooperation with the European Border and Coast Guard. For its objective to enhance compliance with fundamental rights at the external borders, the Commission referred to the proposed Screening Regulation. ${ }^{4}$ In order to strengthen the governance on Schengen, the Commission's Communication was accompanied by a proposal for amending the SEMM, which includes proposals to better monitor and assess Member States' performance on fundamental rights. ${ }^{5}$ In addition, the Commission announced its intention to make a more systematic use of the evaluation and monitoring cycle for starting infringement procedures. ${ }^{6}$ The material norms of the SBC are not mentioned as one of the three pillars. ${ }^{7}$ In the next subparagraphs, I will analyse the current rules on border controls and fundamental rights, and the need for more rules or more clarity. Afterwards, I will assess the current problems with evaluating and monitoring the application of the fundamental rights obligations, and to what extent the proposed revision of the SЕMM will resolve these problems.

\subsubsection{Schengen Borders Code}

Article 4 SBC obliges Member States to apply the Regulation in full compliance with relevant Union law, including the Charter of Fundamental Rights of the European Union ('the Charter'), relevant international law and fundamental rights. The provision explicitly refers to the Geneva Convention and obligations related to access to international protection, in particular the non-refoulement principle, and recalls the need for decisions to be taken on an individual basis. ${ }^{8}$ The reference to relevant Union law relates to the EU asylum acquis, more

$2 \operatorname{COM}(2021) 277,2$ June 2021.

$3 \operatorname{COM}(2021) 277,2$ June 2021, p 4.

$4 \operatorname{COM}(2021) 277,2$ June 2021, p 6, and сом(2020)612, 23 September 2020.

$5 \operatorname{com}(2021) 277$, 2 June 2021, pp 2O-21, and $\operatorname{com}(2021) 278$, 2 June 2021.

$6 \operatorname{com}(2021) 277, \mathrm{p} 21$.

7 The Commission however announced a proposal for an amendment regarding internal border control, in response to the Covid-19 crisis, СоM(2021)277, 2 June 2021, p 18.

8 The non-refoulement principle is also enshrined in Article 78(1) TFEU and Article 18 and 19 of the Charter. 
specifically the right to access to an asylum procedure as enshrined in Article 6 of the Asylum Procedures Directive. ${ }^{9}$ Once people have expressed their intention to seek international protection, the right to dignified reception circumstances applies as well. ${ }^{10}$ Apart from the Geneva Convention, the reference to international law also relates to the case-law of the ECHR on Article 3 and to the prohibition of collective expulsions as enshrined in Article 4 of Protocol 4. Article 14 (2) SBC requires that a refusal of entry has to be based on a substantiated decision, stating the precise reasons for the refusal, taken by a competent authority. According to paragraph 3 of Article 14, the decision should be open to appeal, which however does not suspend the decision to refuse entry. ${ }^{11}$ This implies that any refusal at the border must be based on an individual assessment and be accompanied by a formal decision. The obligation to give every person the opportunity to ask for asylum or other forms of protection, not only implies the prohibition of pushbacks, but also calls in question if Member States are allowed to obstruct attempts to approach or reach their borders. Finally, the importance of the Charter of Fundamental Rights goes beyond the asylum related provisions, as it also touches upon other rights, such as the right to dignity (Article 1), the right to liberty (Article 6), the rights of the child (Article 24) and the right to an effective remedy (Article 47). ${ }^{2}$ The obligation to treat people with dignity, in particular regarding vulnerable persons, and to refrain from discrimination, has been laid down in Article 7 SBC as well. ${ }^{13}$ Furthermore, Article 14(1) SBC stipulates that third-country nationals who do not fulfil all the entry conditions shall be refused entry to the territories of the Member States, by means of a substantiated decision, without prejudice to the special provisions concerning the right to asylum and international protection.

There is no indication that a future proposal amending the SBC will entail a revision of the provisions related to fundamental rights. Although the material norms seem to be clear, and the Schengen Handbook explains how to treat

9 Article 3 of Directive 2013/32 provides it is also applicable to asylum requests lodged at the borders, in the territorial waters and transit zones of the Member States.

10 See Directive 2013/33 (Reception Conditions) Article 1 read in conjunction with Article 2(a) and 2(b). For the definition of an application for international protection, see Directive 2011/95 (Qualifications Directive) Article 2(h).

11 If the refusal of the entry is based on the $\mathrm{SBC}$, this right to appeal has to be in accordance with the right to an effective remedy as enshrined in Article 47 Charter of Fundamental Rights. See also case C-23/12 Zakaria, EU:C:2013:24, paras 33, 34 and 40.

12 In its judgment Zakaria, paragraph 40, the Court of Justice ruled that border guards performing their duties are required to fully respect human dignity. In the same paragraph it underlined that the right to appeal as laid down in Article 13 SBC, must be applied in accordance with Article 47 of the Charter.

13 See also recital 36 sвc. 
(potential) asylum seekers, ${ }^{14}$ the Fundamental Rights Agency observed that while implementing them, border guards suffer from a lack of clarity regarding procedural safeguards, for instance in the context of an interview after apprehension in connection with an unauthorised border crossing. There are also different understandings of what constitutes an indication for international protection needs, how to handle applications, or what are the limits of operational cooperation with neighbouring third countries. Furthermore, a victims-focused approach when combating organised crime at the borders is lacking. ${ }^{15}$ The Agency developed guidance on these matters, to be used at border-crossing points as well as controls during border surveillance. It focuses on treating people with dignity, identifying and referring vulnerable people, the rules on necessity and proportionality when using force, safeguards when holding people at borders and procedural safeguards, including data protection rules. ${ }^{16}$

The SвC leaves some national discretion on how to implement the obligation to prevent and discourage unauthorised border crossing, as provided in Article 13 SBC. For instance it does not exclude the erection of fences, which is increasingly used by Member States with external land borders. ${ }^{17}$ Fences restrict access to an asylum procedure and endanger the non-refoulement principle and the right to human dignity. The Schengen Handbook, which only attributes two pages to border surveillance, is silent on this phenomenon: it only recommends to bring people, including asylum seekers, who tried or have managed to cross the border without authorisation, to the nearest border crossing point. ${ }^{18}$ Especially if a fence lacks gates which are at reasonable distance from each other or if border-crossing points are not accessible, compliance with Article 4 SBC cannot be guaranteed.

In order to guarantee access to asylum, access to border crossing points are key. In the (on other aspects widely contested) N.D. and N.T. versus Spain judgment, the ECtHR rightly argued that 'In the absence of appropriate arrangements [for border crossing], the resulting possibility for States to refuse entry to their territory is liable to render ineffective all the Convention provisions designed to protect individuals who face a genuine risk of persecution.' ${ }^{19}$

\footnotetext{
14 Schengen Handbook, C(2019)7173, para 12.

15 European Union Agency for Fundamental Rights (FRA), 'Migration: Fundamental Rights issues at land borders' (Luxembourg: Publications Office of the European Union, 2020) 35 .

16 Ibid, 44 .

17 Ibid, 13 .

18 Schengen Handbook, C(2019)7131, 103-104.

19 N.D. and N.T. vs Spain Applications nos 8675/15 and 8697/15 (ECtHR, 13 February 2020) para 209.
} 
Despite reports evidencing how asylum seekers where kept away from access to an asylum procedure at the Ceuta and Mellilla fences, the Court failed to formulate concrete criteria on 'appropriate arrangements'. The fencing but also the large-scale pushbacks make the need for clarity more and more urgent. At the moment for instance, there is no border-crossing point in the Evros region, where pushbacks have become a standardised practice and policy. ${ }^{20}$ The Commission formally discourages the erection of fences, including the use of technologies to deter persons to approach the border, but it facilitates this development by funding them. ${ }^{21}$ There is no clear distinction between what could still fall under the definition of preventing unauthorised entry, and therefore be permissible, for instance helicopters or camera's to detect persons in advance, and what constitutes a potential breach of fundamental rights, be it the right to data protection or the right to asylum. The SBC empowers the Commission to adopt delegated acts for additional measures governing border surveillance, but until now, such a delegated act has never been adopted. ${ }^{22}$ The questions raised here, justify the establishment of stricter criteria to guarantee access to protection. That said, use of violence and pushbacks constitute undoubtedly a breach of fundamental rights as referred to in Article 4 SBC.

The practices in recent years at EU-external borders and some parts of the internal borders, give every reason for concern about state compliance with Article 4 SBC. NGOs, national monitoring bodies and international organisations have presented a large number of cases of fundamental rights violations, pushbacks and collective expulsions at EU external borders. Reports by actors like Amnesty International, ${ }^{23}$ Human Rights Watch, ${ }^{24}$ Border Violence

20 Aikaterini Drakopoulou, Alexandros Konstantinou and Dimitris Koros A, 'Border management at the external Schengen Borders: border controls, return operations, and obstacles to effective remedies in Greece', in Sergio Carrera and Marco Stefan (eds), Fundamental Rights challenges in border controls and expulsion of irregular immigrants in the European Union. Complaint Mechanisms and Access to Justice (Routledge 2019).

21 Costica Dumbrava, 'Artificial Intelligence at EU borders. An overview of applications and key issues', (EPRS July 2021); Sam Edwards, 'The high-tech "makeover" of Europe's deadly border with Africa', (Rest of the World, 26 May 2021) <https://restofworld.org/2021/ replacing-razor-wire-with-surveillance-technology-in-melilla/> accessed 11 October 2021.

22 Article 13(5) jo Article 37 Regulation 2016/399.

23 Amnesty International, 'Europe: pushback practices and their impact on the human rights of migrants and refugees' (10 February 2021) < https://www.amnesty.org/en/documents/ior4o/3669/2021/en/> accessed 11 October 2021.

24 Human Rights Watch, 'Frontex failing to Protect people at EU Borders' <https://www .hrw.org/news/2021/06/23/frontex-failing-protect-people-eu-borders $>$ accessed 11 October 2021. 
Monitoring Network ${ }^{25}$ and Refugee Support Aegean ${ }^{26}$ indicate a pattern of behaviour by border- and coastguards that puts lives at risk at sea, jeopardises access to asylum and uses violence to deter people. The Greek Ombudsman, who has been investigating alleged cases of pushbacks for years, released an interim report in April 2021 on pushbacks at the Greek-Turkish land border, in which he noted the lack of investigations and proper responses by Greek authorities. ${ }^{27}$ In December 2020, a complaint was filed at the UN Human Rights Committee on collective expulsions undertaken by the Croatian government. ${ }^{28}$ Representatives of international or intergovernmental organisations like the $\mathrm{OHCHR},{ }^{29}$ the UN Special Rapporteur on the rights of migrants, ${ }^{30}$ the Commissioner for Human Rights, ${ }^{31}$ the European Committee for the Prevention of Torture, ${ }^{32}$ and the Parliamentary Assembly of the

25 See recent reports from the Border Violence Monitoring Network, "The Annual Torture Report 2020' (May 2021); 'Balkan Region Report' (June 2021); 'Systematic Human Rights Violations. Border violence, pushbacks and containment in Ceuta and Melilla' (July 2021).

26 Refugee Support Aegean, 'Push backs and violations of human rights at sea: a timeline' (29 December 2020) <https://rsaegean.org/en/push-backs-and-violations-of-human -rights-at-sea-a-timeline/> accessed 11 October 2021.

27 The Greek Ombudsman, 'Alleged pushbacks to Turkey of foreign nationals who had arrived in Greece seeking international protection', (April 2021) <https://www.synigoros .gr/?i=human-rights.en.recentinterventions.791674> accessed 11 October 2021.

28 European Center for Constitutional and Human Rights, 'Case report: Push-backs in Croatia, Complaint before the UN Human Rights Committee'. <https://www.ecchr.eu/ fileadmin/Fallbeschreibungen/Case_report_Croatia_UN_HRC_Dec202O.pdf $>$ accessed 11 October 2021.

29 ОнснR, 'Lethal Disregard. Search and rescue and the protection of migrants in the central Mediterranean Sea', (UN 2020) <https:/www.ohchr.org/Documents/Issues/Migration/ OHCHR-thematic-report-SAR-protection-at-sea.pdf> accessed 11 October 2021.

30 Felipe González Morales, 'Report on means to address the human rights impact of pushbacks of migrants on land and at sea', A/HRC/47/30 <https://documents-dds-ny.un.org/ doc/UNDOC/GEN/G21/106/33/PDF/G2110633.pdf?OpenElement> accessed 11 October 2021.

31 Commissioner for Human Rights, 'A distress call for human rights: the widening gap in migrant protection in the Mediterranean' (Council of Europe March 2021) $<$ https://rm.coe.int/a-distress-call-for-human-rights-the-widening-gap-in-migrant -protectio/168oarabcd > accessed 11 October 2021.

32 CPT, 'Report to the Greek Government on the visit to Greece carried out by the European Committee for the Prevention of Torture and Inhuman or Degrading Treatment or Punishment (CPT) from 13 to 17 March 2020', CPT/Inf (2020) 35, (Strasbourg 2020); See also CPT's report on its mission to Hungary in 2017 - CPT/Inf (2018) 42 - as well as its follow up report where it also touched upon the role of Frontex. 
Council of Europe ${ }^{33}$ explicitly state that EU Member States are violating their international and regional human rights and maritime law obligations when carrying out pushbacks and unlawful collective expulsions against asylum seekers, refugees and migrants arriving to their borders.

\subsubsection{Schengen Evaluation and Monitoring Mechanism (SEMM)}

The findings of the reports mentioned above are absent from the evaluations on the implementation of the SBC by the Member States. That leaves us wondering why: does it have to do with the methodology of the evaluations or with the scope of the evaluation process? The SEMM is an instrument of peer review, which is based on mutual trust but also on the awareness that deficiencies in the implementation of the Schengen acquis by one Member State can affect all others. ${ }^{34}$ In line with Article 70 TFEU, the Mechanism is a shared responsibility; the evaluations are carried out by the Commission together with Member States experts, supported by EU Agencies which act as observers. During the evaluation process, national experts assess practices in other Member States, identify gaps or problems and propose solutions or call for action. Every Member State is evaluated at least once every five years, but if required, they are complemented with ad-hoc evaluations in the form of unannounced visits or revisits. Furthermore, thematic evaluations can be decided to assess the implementation of a specific part of the Schengen acquis across several countries at the same time. ${ }^{35}$ At the end of an evaluation, the Council adopts recommendations towards a specific Member State upon a proposal from the Commission. In order to implement these recommendations, the Member State concerned must submit an action plan and report on the implementation progress every three months. In case of serious deficiencies, shorter time-limits apply. If the situation persists, the Commission could ultimately

33 PACE, 'Pushback policies and practices in Council of Europe Member States', Resolution no. 2099 and Recommendation. no. 2161, adopted 28 June 2019 <https://assembly.coe.int/ nw/xml/XRef/Xref-XML2HTML-en.asp?fileid=28074> accessed 11 October 2021.

34 The Mechanism is laid down in Council Regulation (EU) No 1053/2013 establishing an evaluation and monitoring mechanism to verify the application of the Schengen acquis and repealing the Decision of the Executive Committee of 16 September 1998 setting up a Standing Committee on the evaluation and implementation of Schengen [2013] OJ L 295.

35 Report on the functioning of the SEMm pursuant to Article 22 of Regulation 1053/13. First Multiannual Evaluation Programme (2015-2019), Сом(2020)779, 25 November 2020, para 2.1. 
propose to recommend the reintroduction of internal border controls by other Member States, based on Article 29 sвс. ${ }^{36}$

Apart from the evaluation of the right to protection of personal data, the current mechanism does not include a specific and structural assessment of respect for fundamental rights in the implementation of the Schengen acquis. The first multiannual evaluation programme, which covers the period 20152019, shows that not a single recommendation has been adopted related to refoulement or pushbacks, despite the numerous reports about violations in the Member States concerned. ${ }^{37}$ The fundamental rights-related recommendations mostly concerned procedural safeguards during checks at border crossing points. ${ }^{38}$ The serious deficiencies found in Greece in 2015 and in Spain in 2017 regarding Melilla and Ceuta, which concerned the lack of identification and registration of irregular migrants and the lack of capacity to perform border checks, were not dealt with in connection to fundamental rights either. ${ }^{39}$ However, most pushbacks take place outside border crossing points. Recommendations specifically related to external border surveillance concentrated on the limited territorial scope of the surveillance, limited exchanges of information between external border authorities and limited implementation of the EUROSUR Regulation. ${ }^{40}$ This is not surprising as neither national monitoring bodies nor the Fundamental Rights Agency are involved in the evaluation process, and thus the necessary knowledge and expertise are missing. ${ }^{41}$ The Commission's evaluation report concludes that the assessment of the respect for fundamental rights is not sufficiently integrated in the evaluation mechanism. It emphasizes the need to reflect on improvements, for instance by updating check-lists with fundamental rights, wider participation of FRA and a wider use of its guidelines. ${ }^{42}$ In the proposal for amending the SЕмм, the Commission has worked out this ambition by incorporating the obligation to use the results of other - Union or national - monitoring mechanisms and

36 This happened regarding Greece in 2016, see $\operatorname{com}(2016) 120$, followed by a decision of five Member States to reintroduce internal border controls, Council Implementing Decision (EU) 2016/1989 [2016] OJ L 306, 13.

37 FRA, Fundamental Rights Report 2020 (Report, 2020) 126.

38 Ibid 216 and FRA, Migration: Fundamental Rights issues at land borders (Report, 4 December 2020) para 5.3.

39 See the Commission Staff Working Document swD (2020)327, 25 November 2020, accompanying $\operatorname{COM}(2020) 779$, para 1.4 .

$40 \operatorname{COM}(2020) 779$, para 3.2.1.

41 FRA is only involved in return-related issues, while Frontex is involved in evaluating external border management, visa and return. See $\operatorname{com}(2020) 779$, footnote 13 . 
take into account information provided by third parties. ${ }^{43}$ The Commission proposes a special, accelerated procedure in case of serious deficiencies, which includes deficiencies with a negative impact on the rights of individuals. ${ }^{44}$ Furthermore, unannounced visits can take place without prior notice and fundamental rights must be part of the trainings for Schengen evaluators. ${ }^{45}$ The improvements, combined with the proposals for a more swift and effective response to deficiencies, do not yet guarantee that fundamental rights are effectively assessed. For each multiannual evaluation cycle, the Commission decides together with the Member States on the specific policy areas to be evaluated. So, whether fundamental rights expertise will be included in the scope, still largely depends on a political decision. In order to mitigate the political nature of the decision making on the policy areas, the selection of policy areas and themes should be substantiated and consider reports on fundamental rights compliance by national and international monitoring bodies and human rights organisations. Given the importance of fundamental rights compliance, fundamental rights should feature as a cross-cutting topic in standard check-lists and questionnaires and be a prominent part of all evaluations.

Among the EU institutions, the Commission and Council were not the most vigilant defenders of fundamental rights compliance: both of them kept silent on the numerous reports about pushback practices at the external borders. It is therefore concerning that the European Parliament as the most vocal institution in this regard, plays a marginal role in the current but also the proposed SEMM, which is limited to receiving information. ${ }^{46}$ As most of the documents are already finalized and transmitted under very strict confidentiality rules, which severely hampers access to the relevant documents for members of the European Parliament, it will be difficult for the Parliament to exercise influence or scrutinize the process in a meaningful and transparent way. ${ }^{47}$ As the SEMM is predominantly seen as a peer-to-peer review system, the Council

43 See recital 10 and Article 10 and 11 of the proposal for a new SЕмм, Сом(2021)278, 2 June 2021.

44 See Article 2 (i) and Article 23 of $\operatorname{com}(2021) 278$.

45 See Article 4(2)(c) and 19(4), and Article 16(1) $\operatorname{com}(2021) 278$.

46 See $\operatorname{com}(2021) 278$, Article 12(2) and (4), Article 13(3), Article 21(1), Article 22(3), Article 23(2)(6)(9)(10), Article 24(3)(4), Article 28 and 30.

47 These barriers have been discussed in Elspeth Guild and others, An Analysis of the Schengen Area in the Wake of Recent Developments, (Brussels 2016) 35-37. See also the Interinstitutional Agreement between the Parliament and Council of 12 March 2014, OJ C 95, Framework Agreement on relations between the European Parliament and the European Commission, 20 November 2010, OJ L 304/47, and the Rules of Procedure of the European Parliament, September 2015, Annex viI: confidential and sensitive documents and information. 
managed to exclude the Parliament as a co-legislator in amending the SEMM Regulation..$^{48}$ In response, the Parliament insisted on a consultative role on the SEMM, which is now reflected in the SBC. ${ }^{49}$

\subsection{Standards Related to Accountability and Their Enforcement}

3.1.1 Standards and Practices on National Investigations

Naturally, the SEM does not preclude in any way the Commission from using its enforcement powers under Article 258 TFEU. At the EU level, enforcement of compliance with fundamental rights depends on how the Commission fulfils its role as Guardian of the Treaties. Before 2015, the Commission acted and reacted upon allegations of pushbacks several times, for instance regarding Bulgaria, Greece and Spain. ${ }^{50}$ Since then however, although the number of allegations significantly increased, involving more and more border countries, the Commission became more silent. In response to calls for a more active role, Commissioner Johansson tends to state that the Commission is not an investigative body and therefore not equipped to assess allegations about pushbacks. This unsatisfactory answer would imply that enforcement of compliance with Union law would be limited to acting upon national legislation violating EU rules, but that national practices could not be controlled or corrected.

The Commission is right if it refers to the national authorities as the first actors responsible to investigate any allegation of fundamental rights violations. Under Article 13 ECHR, state authorities are obliged to carry out an effective official investigation in case of complaints or indications that one of the core rights of the ECHR is violated. ${ }^{51}$ According to the ECtHR, the effectiveness of the protection also depends on the specific powers and procedural guarantees offered by alternative (i.e. administrative) remedies. These administrative remedies are complementary and supplementary to judicial

48 The Commission's proposal to base the new mechanism on Article 77(2)e TFEU was rejected by the Council and replaced by Article 70 TFEU, see the first proposal сом(2010)624, 16 November 2010 and сом(2011)0559.

49 See European Parliament's resolution TA-7-2013-026o of 12 June 2013, <https://www .europarl.europa.eu/doceo/document/TA-7-2013-026o_EN.html\#title1> and Recital 20 of Regulation 1053/2013.

50 European Commission, Seventh bi-annual report on the functioning of the Schengen area (1 November 2014-30 April 2015), сом(2015)236, p 8.

$5^{1} \quad$ FRA, 'Migration: Fundamental Rights. Issues at Land Borders', para 4.2.; Mocanu and Others v. Romania App no10865/o9 (ECHR, 178 September 2014) paras 315-326. 
remedies, which have to be ensured anyway, in particular when the misconduct of border guards constitute a crime. ${ }^{52}$ The administrative investigation must be prompt, expeditious and capable of leading to the identification and punishment of the responsible actors. This requires a thorough and active investigation conducted by independently acting persons, where victims are heard and sufficiently involved. ${ }^{53}$ Of vital importance for complaints against pushbacks, as many victims remain outside the state's territory, is that the remedy must be available, prompt, accessible and not hindered by the acts of the state authorities. ${ }^{54}$

Although there is no concrete EU norm obliging a Member State to have an independent investigation procedure concerning complaints against conduct of national border guards, the criteria deriving from Articles 41 and $47 \mathrm{EU}$ Charter give some guidance. According to the CJEU, the right to good administration (Article 41) requires that complaints should be handled impartially, fairly and within a reasonable period of time. ${ }^{55}$ The Court has explained that the requirement of impartiality implies that no member of the concerned institution may exhibit bias or personal prejudice. The institution must provide sufficient guarantees to exclude any justified doubt in this regard. ${ }^{56}$ Carrera and Stefan argue that Article 41 also requires that rectification is obtained of the wrong suffered and that any damage is compensated. ${ }^{57}$ Contrary to its H.N. judgment, the CJEU argued in the Boudljida judgment that Article 41 is only addressed to the EU and its institutions and bodies. However, it referred to the right to be heard that also applies to the Member States as a general principle of EU law. ${ }^{58}$ According to the Court, this right guarantees every person the opportunity to make known his views effectively during an administrative procedure and before the adoption of any decision liable to affect his

$5^{2}$ Sergio Carrera and Mauro Stefan, 'Human rights complaints at international borders or during expulsion procedures', in Sergio Carrera and Marco Stefan (eds) Fundamental Rights Challenges in border controls and expulsion of irregular immigrants in the European Union. Complaint Mechanisms and Access to Justice (Routledge 2020) 261.

53 Armani da Silva v. the United Kingdom App no 5878/08 (ECHR, 30 March 2016) paras 229-239.

54 Muminov v. Russia App no 42502/o6 (ECHR 11 December 2008) para 10o. See also Carrera and Stefan (n 52) 262.

55 Article 41(1) of the Charter. See also C-604/12 H.N., EU:C:2014:302, para 5 o.

56 C-439/11 P, Ziegler SA v. European Commission, EU:C:2013:513, para 155.

57 The right to rectification and compensation is referred to in Carrera and Stefan (n $\left.5^{2}\right)$ p 265 .

$5^{8}$ See H.N., paras 49-50; Case C-249/13 Khaled Boudjlida, EU:C:2014:2431, para 32. The Court refers here to its judgment in case C-482/10 Cicala, EU:C:2011:868, para 28. 
interests adversely..$^{59}$ Although Article 47 of the Charter only refers to the right to appeal, one could argue that a right to an effective remedy implies an adequate complaint procedure as well. In its judgment Zakaria, the Court made clear that Member States have to 'provide in their domestic legal system for the appropriate legal remedies to ensure, in compliance with Article 47 of the Charter, the protection of persons claiming the rights derived from Article 6 Regulation no. 562/2006. ${ }^{\prime 0}$ This provision obliges Member States to ensure that border guards exercise their border control activities in compliance with the respect for human dignity and non-discrimination. One should also bear in mind that pushbacks do not only relate to bad behavior or other forms of misconduct, but also imply a decision to refuse entry, with far reaching legal consequences. In the absence of a formal right to appeal, due to the omission to issue a formal refusal, at least such conduct should be scrutinized thoroughly and impartially. But even in case of a formal refusal of entry and subsequent return procedures, the procedural safeguards on remedies as laid down in Article 13 Return Directive, only offer protection in Member States that did not apply Article 2(2)a of that Directive. ${ }^{61}$

In the light of these requirements, Carrera and Stefan observe that many complaint mechanisms in the Member States show deficiencies and a high level of fragmentation. As border control often involves several authorities and actors, each with their own internal complaint procedure, and the involvement of both administrative and criminal procedures, it is not always easy to identify the responsibility for a certain misconduct or abuse of power and thus to know the right channel. ${ }^{62}$ For example, in its interim report of April 2021, updated to 31 December 2020, the Greek Ombudsman reported that in response to complaints about pushbacks, the competent police services in most cases send a formal and more or less standardized letter, concluding that there is no indication of wrongdoing on the part of the police officers and that the complaints are likely to come from traffickers aiming to compromise the operational capabilities of the police. ${ }^{63}$ The Ombudsman's search for information within the

59 Khaled Boudjlida, paras 33-36. The Court refers to case C-166/13 Mukarubega, EU: C:2014:2336, paras 44-45.

6o Zakaria (n 13) para 40.

61 Article 13 ECHR is not included in the minimum safeguards of Article 4(4) Directive 2008/115.

62 Carrera and Stefan (n $\left.5^{2}\right) 268$.

63 This own-initiative investigation into allegations of pushbacks was launched on 9 June 2017. The Greek Ombudsman, 'Alleged pushbacks to Turkey of foreign nationals who had arrived in Greece seeking international protection', Interim Report, 28 April 2021, part VII. 
organization of the police, only led to replies that no evidence or indications emerged that would be a necessary basis for a formal internal investigation for human rights violations of acts or omissions by police officers. At the same time however, the police directorate of Orestiada replied to the Greek Ombudsman that it deterred the crossing from Turkey to Greece of approximately 57,000 persons between 2017-2018. ${ }^{64}$ The Ombudsman called for the Greek police to formally investigate allegations of pushbacks that have not been investigated insofar, and for the authorities to develop a specific and detailed operational plan to address the possibility of private groups or militias carrying out illegal pushbacks. ${ }^{65}$ The NGO Border Violence Monitoring Network criticized the second recommendation by emphasizing that it is beyond doubt that the pushback practices are standardized and take place under the control of the Greek government. ${ }^{66}$ UNHCR informed the European Parliament that in 2020, it had filed testimonies about 23 alleged pushbacks at the land border and communicated that it had recorded 110 reported incidents at sea between Greece and Turkey; for the first quarter of 202124 additional cases were documented. In one case, the Ministry of Shipping and Island Policy, and in another one the Ministry of Citizen Protection/Hellenic Police replied that no such incidents occurred. ${ }^{67}$

\subsection{2}

The Commission's Role to Ensure Compliance with Fundamental Rights

The above-mentioned reports should have made the Commission aware that it cannot take for granted that national governments systematically carry out a thorough investigation into complaints about pushbacks. Especially in case of consistent and well substantiated reports of authoritative actors claiming that fundamental rights are violated at the border, the Commission cannot rely on a formal denial by the national authorities. However, this is what is actually happening in the case of allegations about the Greek and the Croatian authorities. Since November 202O, the EU Ombudsman is investigating a complaint from Amnesty International against the European Commission regarding its lack of response towards the Croatian authorities. ${ }^{68}$ The Ombudsman's inquiry

\footnotetext{
64 Ibid, part v.

65 Ibid, part viII.

66 'Response to Greek Ombudsman's Interim Report on Alleged Pushbacks to Turkey', Border Violence Monitoring Network, 14 May 2021, Thessaloniki, Greece.

67 'Response to the LiBE Frontex Scrutiny Working Group request for information', UNHCR Representation for EU affairs, Belgium, Ireland and the Netherlands, 25 May 2021.

68 'Ombudsman inquiry opened on how European Commission seeks to ensure protection of fundamental rights in border management operations by Croatian authorities', Case
} 
focuses on how the Commission seeks to ensure that fundamental rights are respected by Croatian authorities during border management operations. The complainant, Amnesty International, argued that the Commission turned a blind eye to the reports of persistent abuses and failed to establish an independent monitoring mechanism to ensure that Croatian authorities respected fundamental rights while conducting EU-funded border operations targeting migrants and refugees.

This case is particularly salient as Croatia as a candidate Schengen country is subject to the Schengen Evaluation and Monitoring system. ${ }^{69}$ In October 2019, the Commission had presented its conclusion of the 2019 Schengen evaluation of the external border that no deficiencies related to fundamental rights were identified. ${ }^{70}$ The Commission admitted that pushbacks and the use of violence by border guards 'remained a challenge', but that a part of the emergency funding to reinforce border management would be dedicated to a new monitoring mechanism. The Commission invited the Council to fully integrate Croatia into the Schengen Area. However, after the release of this conclusion, it took the Commission (pressed by the European Parliament) almost two years to persuade the Croatian government to establish a monitoring mechanism. In June 2021, it signed an agreement with a number of national stakeholders on the establishment of an Independent Monitoring Mechanism, including a coordination board and an advisory board, in which the Commission participates. ${ }^{71} \mathrm{In}$ its reply to the questions from the EU Ombudsman of July 2021, the Commission stated that there is no definition of a 'monitoring mechanism' in the context of EU emergency funding under Article 2 Regulation 515/2014, which applies in cases of urgent and exceptional pressure at the Union's external borders. The Commission emphasised that setting up an independent monitoring mechanism is not a prerogative for funding under the 'Emergency Assistance granting scheme' (EMAS), as it falls under the competence and responsibility of the Member States. ${ }^{72}$ For the same reason, the

1598/2020/MMO, opened on 6 November $2020<$ https://www.ombudsman.europa.eu/ en/case/en/57811> accessed 11 October 2021.

69 Article 1(1)(b) Regulation 1053/2013, and $\operatorname{com}(2020) 779$, footnote 8.

70 Communication on the verification of the full application of the Schengen acquis by Croatia, Сом (2019) 497, 22 October 2019.

71 Letter of Commissioner Johansson of 21 August 2021, in reply to a letter of a group of MEPS.

72 EMAS funding can be granted in emergency situations, as part of the Asylum Migration Integration Fund (AMIF Regulation 516/2014) and the Internal Security Fund (ISF Regulation 515/2014). 
Commission is not competent to verify the establishment or functioning of such a monitoring mechanism. ${ }^{73}$

This leads to the question if the emergency part or other parts of the funding of border management is not conditional at all to compliance with EU law. As the relevant regulation aims to guarantee access to international protection and compliance with human rights law and international maritime law, the Commission should be able to require compliance with these obligations. ${ }^{74}$ In order to press the Commission to use all available instruments to combat human rights violations at the border, the European Parliament recommended in July 2021, in the context of its investigation into Frontex, to the Commission to make compliance with fundamental rights conditional upon funding of border management. ${ }^{75}$

The Commission seems reluctant to use the instruments it has at its disposal to enforce compliance with fundamental rights at the border: neither the infringement procedure, nor the funding framework, not even the Schengen accession process. That leaves us wondering whether the Commission has a strategy to end the impunity regarding fundamental rights violations at the border, which have exacerbated during recent years. When asked about this compliance gap, Commissioner Johansson's standard answer is better monitoring. This includes working towards an agreement on a monitor mechanism with Croatia, and negotiations with the Greek government on independent monitoring at the Greek-Turkish land border. But what will monitoring lead to, if the current thorough and consistent reports from authoritative actors about pushbacks can be disregarded by national authorities without any consequences? And what can monitoring bring, if the pushbacks do not take place incidentally but are a standardized practice and policy of the Member States concerned?

\subsection{The Screening Regulation Proposal}

Without a convincing response to these legitimate questions, the Commission persists that monitoring mechanisms can prevent fundamental rights violations. In September 2020, it introduced a mandatory national fundamental rights border monitoring mechanism in its proposal for a Screening Regulation,

73 See the Commission's reply in case 1598/2020/MMO <https://www.ombudsman.europa. $\mathrm{eu} / \mathrm{en} / \mathrm{case} / \mathrm{en} / 57811>$ accessed 11 October 2021.

74 See i.a. Article 3(2)(b) and 3(4) and (5) Regulation 515/2014.

75 Report on the fact-finding investigation on Frontex concerning alleged fundamental rights violations, Frontex Scrutiny Working Group, LIBE committee European Parliament, 14 July 2021, 4B. Due to the scope of the report, this recommendation was limited to Member States having a joint operation with Frontex. 
which is a vital element of the New Pact on Asylum and Migration. ${ }^{76}$ The proposed Regulation aims to "contribute to the protection of the Schengen area and ensure sufficient management of irregular migration'.77 It includes rules to harmonise the border-checks by Member States, in particular through the introduction of a 'pre-entry screening' of third country nationals. The Regulation is characterized by its hybrid nature, combining elements of both the Schengen acquis, the asylum acquis and the rules on return, which should, according to the Commission, lead to 'enhancing the synergies' between these three areas during external border controls. ${ }^{78}$ But the Regulation is also a mixture of EU law and national discretion, which hampers the aim of harmonization. After a brief introduction of the main elements of the Screening Regulation, I will analyse to what extent the proposed monitoring mechanism will be an effective tool for combatting fundamental rights violations at the border.

\subsubsection{The Screening Procedure}

The screening procedure - which applies to third country nationals who are apprehended in connection with an unauthorized crossing of an external border or after disembarkation, following a search and rescue operation - includes a preliminary health and vulnerability check, an identity check against information in European databases, registration of biometric data and a security check, in particular through a search of the sis. ${ }^{79}$ These checks carried out at the external border are followed by the completion of a de-briefing form, which not only includes information on the identity and nationality, but also the reasons for unauthorized arrival, prior asylum applications, travel routes and facilitators of the unauthorized travel..$^{80}$ On the basis of this information, the 'competent authorities' refer the person to the next appropriate procedure, which can be a return procedure, an asylum procedure or relocation under the new Dublin Regulation, the proposed Asylum Management and Migration

76 Proposal for a Regulation introducing a screening of third country nationals at the external borders and amending Regulations 767/2008, 2017/2226, 2018/1240 and 2019/817, $\operatorname{com}(2020) 612,23$ September 2020. See also the Communication on the New Pact, сом (2020)6o9, 23 September 2020.

$77 \quad$ сом $(2020) 612, \mathrm{p} 2$.

$78 \operatorname{com}(2020) 612, \mathrm{p} 1$.

79 See Article 3 and 6 of the proposal. In order to ensure access to all relevant databases during the screening procedure, the proposal for a Regulation has been supplemented with a proposal to amend Regulations 2019/816, 2019/818, 2018/1726 and 2018/1862, СОм(2021)96, 2 March 2021.

8o Article 13 of the proposal. 
Regulation. ${ }^{81}$ The screening procedure ends after this referral or in any case after five days, regardless if the checks have been completed. ${ }^{82}$

The information gathered during screening determines to which asylum procedure the authorities will refer the asylum seeker: the asylum border procedure, which foresees an accelerated examination while being detained at the border, or to the regular asylum procedure where asylum seekers enjoy the normal standards and time-limits. ${ }^{83}$ For persons who do not fulfil the conditions of entry and have not applied for international protection, two different return procedures can apply. If a Member State has not made use of the optional clause of Article 2(2)(a) of the Return Directive, all procedural safeguards of the directive apply. However, if a Member State has applied this optional clause, the Directive does not apply towards a third country national after having been apprehended and intercepted at the very time of irregular crossing or near that border after crossing. ${ }^{84}$ In those cases, only national standards apply, for instance on detention or the right to appeal. ${ }^{85}$ This national discretion is limited by the minimum rules of Article 4(4) of the Return Directive and by the Charter of Fundamental Rights. If that person requests asylum, the optional clause cannot be applied after the final rejection of that application. ${ }^{86}$ Ten Member States with external land borders have applied this optional clause, whereas four of them do apply the Return Directive in full. ${ }^{87}$ Although the Commission introduced evaluations in the field of return in the SEMM in order to ensure a correct implementation of the Return Directive, this optional clause hampers the realization of sufficient procedural safeguards

81 See Article 14 of the proposal. The AmmR is proposed in $\operatorname{com}(2020) 610,23$ September 2020.

82 Article 14 of the proposal.

83 For the asylum border procedure see Article 41 of the amended proposal for the Asylum Procedures Regulation, $\operatorname{COM}(2020) 611$, for the standard asylum procedure see the proposal for the Asylum Procedures Regulation, $\mathrm{COM}(2016) 467$.

84 Case C-47/15 Affum, EU:C:2016:408, para. 72. See also Steve Peers, EU Justice and Home Affairs Law (OuP 2016) 504 and Izabella Majcher, The European Union Returns Directive and its compatibility with International Human Rights. An analysis of Return Decision, Entry Ban, Detention and Removal (Brill 2020) para 1.1.1.2.

85 See also Article 14(1) of $\operatorname{COM}(2020) 612$, which for those cases refers to Article 14 SBC.

86 See the final sentence of Article 2(2)(a): 'and who have not subsequently obtained an authorisation or a right to stay in that Member State', see also recital 9. For a historical explanation, see Fabian Lutz, The Negotiations on the Return Directive (Wolf Legal Publishers 2010) para 2.2.1.

87 The Member States which opted out are Bulgaria, France, Greece, Hungary, Latvia, Lithuania, Poland, Romania, Slovenia and Spain. The Member States which apply the Directive are Croatia, Estonia, Finland and Slovakia. See FRA, 'Migration: Fundamental Rights issues at land borders', table 2, p 8. 
at the external border. ${ }^{88} \mathrm{~A}$ mandatory application of the Return Directive in border areas would be more in line with the characterization of the Return Directive as part of the Schengen Acquis, and it would make the SEMM more effective as well. ${ }^{89}$ The Commission however did not seize the opportunity with its proposal to recast the Return Directive to remove this optional clause. ${ }^{90}$

\subsubsection{The National Monitoring Mechanism}

Article 7 of the proposed Screening Regulation defines the requirements for an independent monitoring mechanism, which includes the obligation to monitor (paragraph 2) and to investigate allegations of non-respect for fundamental rights (paragraph 1). ${ }^{91}$ The monitoring relates to compliance with EU law and international law, including the Charter of Fundamental Rights, during the screening. The scope of secondary EU law is limited to the Screening Regulation and the Schengen Borders Code, as the Screening Regulation provides that during the screening the secondary asylum legislation, such as the Reception Conditions Directive and the Asylum Procedures Directive does not apply. ${ }^{92}$ This also limits the monitoring of detention to compliance with the applicable national rules and ECtHR case-law. As there are huge differences regarding the resources, mandate and level of independence of national human rights institutions, Ombudspersons, national preventive mechanisms or other monitoring bodies, a more effective monitoring would require criteria on these aspects in the Regulation. ${ }^{93}$ The most concerning limitation of the monitoring however is its scope, which only applies 'in relation to the screening'. If this wording is interpreted as the screening procedure as such, the mechanism will not combat and prevent pushbacks, as pushbacks imply an informal process being taken away or pushed back to the territory of a third country, which undermines the guarantee of any screening procedure

88 Commission Staff Working Document Accompanying the First Multiannual Evaluation Programme (2015-2019), swD(2020)327, 25 November 2020, para 3.

89 See recitals $25^{-3} 30$ of Directive $2008 / 115$, and the Commission staff working document $\operatorname{SWD}(2020) 327$, para 3.1.

$90 \operatorname{COM}(2018) 634,12$ September 2018. An amendment in Parliament with this aim is under negotiation, see Draft Report on the Commission proposal for the recast Return Directive, rapporteur Tineke Strik, 21 February 2020, 2018/o329 (COD), amendment no. 4O.

91 See also recital 23 of the proposal.

92 See recital 16 of the proposal, and page 5 of the Explanatory Memorandum of the proposal.

93 The obligation to 'put in place adequate safeguards to guarantee the independence of the mechanism', in Article 7(2) is too permissive without a clear definition or criterion. 
at all. ${ }^{94}$ Having border surveillance covered in the Regulation would enable the Commission to enforce an effective monitoring mechanism by 'monitoring the monitors', and ultimately, the respect for fundamental rights. In this way Article 7 of the Screening Regulation would add another instrument to the toolbox of the SEMM.

The Screening Regulation also creates a legal obligation in EU law to adopt 'relevant provisions to investigate allegations of non-respect for fundamental rights in relation to the screening. ${ }^{95}$ Although this offers the Commission a tool to monitor the existence and effectiveness of such mechanism, concrete criteria in line with the standards as set out in paragraph 3.1.1. are lacking. The importance of strengthening the obligations regarding investigations of allegations is shown by the current implementation of Article 111 of the EUCG Regulation. ${ }^{96}$ Paragraph 7 obliges Member States which deploy border guards at Frontex operations, to set up a mechanism to investigate fundamental rights allegations which are submitted at the Agency, and report back to the Fundamental Rights Officer on the findings and follow-up. It proves to be extremely difficult for the Fundamental Rights Officer to let Member States comply with this obligation. Sanctions for non-compliant Member States built in the Screening Regulation, could facilitate enforcement of this obligation. ${ }^{97}$ A notification requirement as regards the relevant body competent and responsible for investigating allegations of fundamental rights abuses by border guards at the borders would force Member States to actually designate such a body. ${ }^{98}$

94 See also Anja Radjenovic, 'Pushbacks at the EU's external borders' (E PRs, March 2021); Costica Dumbrava, 'Screening of third-country nationals at the EU's external borders' (EPRS, November 2020); Marco Stefan and Roberto Cortinovis, 'Setting the right priorities: is the new Pact on Migration and Asylum Addressing the issue of pushbacks at EU external borders?' (ASILE 25 November 2020) <https://www.asileproject.eu/setting -the-right-priorities-is-the-new-pact-on-migration-and-asylum-addressing-the-issue-of -pushbacks-at-eu-external-borders/> accessed 11 October 2021.

95 Article 7(1) Screening Regulation.

96 Regulation 2019/1896.

97 Meijers Committee, 'Comments on the Migration Pact - Asylum Screening Regulation' (CM 2010, 2020) para 2.

98 E. Guild has proposed this as an amendment on Article 111(4) EUCG Regulation, in order to ensure a national complaint mechanism for complaints submitted in the framework of Frontex Joint Operations. See Eslepth Guild, 'Frontex' NEMIS 2021/2 <https://cmr.jur .ru.nl/nemis/nemis.2021.2.pdf> accessed 11 October 2021. 


\section{Frontex and Its Mandate to Monitor and Promote Fundamental Rights Compliance}

\subsection{Legal Framework}

Since the establishment of Frontex, its responsibilities towards fundamental rights compliance have increased with every legislative process amending or replacing the Regulation on Frontex. According to the legal framework, the Agency has not only the negative obligation to respect fundamental rights by not actively violating them, but also positive obligations to protect fundamental rights. Among its tasks are 'monitoring compliance with fundamental rights' and ensuring 'a continuous and uniform application of the Union acquis on fundamental rights. ${ }^{9}$ In its Fundamental Rights Strategy, based on Article $80(1)$ of the Regulation, Frontex expresses its commitment to respecting and promoting fundamental rights, considering these elements as unconditional and integral components of effective European integrated border management. ${ }^{100}$ Fulfilling this responsibility requires that Frontex is alert to every signal about fundamental rights violations, conducted by border guards from host Member States or Frontex teams. A number of internal mechanisms aim to ensure a low threshold for submitting signals and a proper examination, like the serious incidents reporting system, guidelines on whistleblowing, and the supervisory mechanism to monitor the use of force by Frontex staff. ${ }^{101}$ Victims of human rights violations can use the complaint mechanism. ${ }^{102}$ In addition, the Fundamental Rights Officer is equipped to present concerns, opinions and recommendations to the executive director in case of fundamental rights concerns. ${ }^{103}$ Moreover, Frontex needs to gather and analyse all relevant information to create a sound basis for taking a decision to launch, suspend or withdraw from a joint operation. Frontex is not allowed to continue such an operation in case of fundamental rights violations that are serious or likely to persist. ${ }^{104}$ As a consequence, an activity may not be launched if already serious reasons for termination exist, which could lead to serious fundamental

\footnotetext{
99 Article 10(1) (e) and (s) Regulation 2019/1896.

100 The Management Board has adopted the FR Strategy on 15 February 2021.

101 See Article 19 of the Code of Conduct applicable to all persons participating in Frontex Operational Activities, ED Decision No R-ED-2017-32; Frontex, Management Board Decision 17/2019 of 18 July 2019; Frontex, Management Board Decision 7/2021 of 20 January 2021.

102 See for the complaint mechanism Article 111 EUCG Regulation.

103 Article 109 EUCG.

104 Article 46(4) EUCG.
} 
rights violations. ${ }^{105}$ Such decisions have to be based on the outcomes of the reporting mechanisms, including complaints, serious incident reports, and reports from relevant international organisations and Union institutions. ${ }^{106}$ In addition, risk analyses, vulnerability assessments and situational pictures feed into decisions by the executive director related to Joint Operations. ${ }^{107}$

\subsection{Implementation of Fundamental Rights Related Obligations}

Despite these procedural guarantees, there are hardly any public signs that Frontex took serious account of the allegations on fundamental rights violations by the Member States, expressed by external organisations. It was only in autumn 2020, after the release of a report from investigative journalists blaming Frontex of being involved in violations, that the Management Board of Frontex took allegations seriously. The journalists claimed to have found evidence that Frontex had knowledge of the pushbacks, did nothing to ensure compliance with legal obligations, and in some cases even cooperated with the authorities carrying out the illegal pushbacks and collective expulsions. ${ }^{108}$ In November 2020, the Management Board established a Working Group Fundamental Rights and Legal Operational Aspects of Operations (wG FRaLO) to investigate the specific allegations raised by the investigation of the journalists regarding alleged involvement of Frontex with pushbacks in the Eastern Mediterranean. ${ }^{109}$ In its final report of 1 March 2021, the Management Board concluded that out of the thirteen incidents put forward by the Bellingcat report, eight cases had not caused a violation of the Frontex Regulation, and five examined incidents were not yet, or could not yet be clarified. ${ }^{110}$ At its extraordinary meeting in May 2021, the Management Board concluded that in

\footnotetext{
105 Article 46(5)EUCG.

106 Article 46(6)EUCG.

107 Articles 37(3) and 39(3), see also Articles 29, 32, 25 and 26 EUCG.

108 Nick Waters, Emmanuel Freudenthal and Logan Williams, 'Frontex at Fault: European Border Force Complicit in “Illegal” Pushbacks' (Bellingcat 23 October 2020) <https://www. bellingcat.com/news/2020/10/23/frontex-at-fault-european-border-force-complicit-inillegal-pushbacks/> accessed 15 October 2021.

109 Frontex, Decision of the Management Board no. 39/2020 <https://frontex.europa.eu/ assets/Key_Documents/MB_Decision/2020/MB_Decision_39_2020_on_the_establish ment_of_the_Management_Board_Working_Group_FRaLO.pdf $>$ accessed 11 October 2021 .

110 Frontex, 'Conclusions of the Management Board's meeting on 5 March 2021 on the report of its Working Group on Fundamental Rights and Legal Operational Aspects of Operations in the Aegean Sea' <https://frontex.europa.eu/media-centre/management-board-updates/ conclusions-of-the-management-board-s-meeting-on-5-march-2021-on-the-report-of -its-working-group-on-fundamental-rights-and-legal-operational-aspects-of-operations -in-the-aegean-sea-aFewSI> accessed 15 October 2021.
} 
two out of the five cases, there is "strong belief that the presented facts support an allegation of possible violation of fundamental rights or international protection obligations such as the principle of non-refoulement, and that it cannot be excluded that the incident has characteristics of a case of unprocessed return and violation of the principle of non-refoulement". ${ }^{111}$ In response to the same allegations the European Parliament established a Frontex Scrutiny Working Group (FSWG), tasked with an inquiry into the role of Frontex regarding allegations of fundamental rights violations. On 14 July, this scrutiny group presented its findings. ${ }^{112}$

Meanwhile, other investigations are pending or have recently been finished. The European Court of Auditors released its report on the effectiveness of Frontex's support to external border management on 7 June 2021. ${ }^{113}$ In November 2020, the European Ombudsman started an own-initiative inquiry on the functioning of the complaint mechanism, which was released on 15 June 2021. ${ }^{114}$ In December 2020, OLAF opened an investigation concerning the Agency, which is expected to be presented in autumn 2021. ${ }^{115}$

\subsection{The Parliamentary Investigation}

The inquiry led to the conclusion of the European Parliament that the Agency, although it found evidence in support of allegations of fundamental rights violations conducted by host Member States, including in the context of a Joint Operation, failed to address and follow-up on these violations promptly, vigilantly and effectively. The Parliament concludes that as a result, Frontex did not prevent these violations, nor reduced the risk of future fundamental rights violations. ${ }^{116}$ The scrutiny identified a whole list of different types of deficiencies. On the one hand, the inquiry showed the non-implementation of obligations in the 2019/1896 Regulations, specifically relating to fundamental

111 Explanatory note on the state of play of the five incidents reviewed in the final report of the management board working group on fundamental rights and legal and operational aspects of operations, 23 April 2021.

112 Frontex Scrutiny Working Group (FSWG), 'Report on the fact-finding investigation on Frontex concerning alleged fundamental rights violations' and the Annex to this report (14 July 2021) <https://www.europarl.europa.eu/cmsdata/238156/14072021\%2oFinal\%2O Report\%20FSWG_en.pdf> accessed 11 October 2021.

113 European Court of Auditors, Special Report 08/2021, "Frontex's support to external border management: not sufficiently effective to date".

114 European Ombudsman, Decision OI/5/2020/MHZ, 15 June 2021, para 18, <https://www .ombudsman.europa.eu/en/decision/en/143108> accessed 11 October 2021.

115 According to media reports, this investigation concerns allegations of harassment, misconduct and migrant pushbacks.

116 FSWG (n 112) para 1C. 
rights compliance. This concerned procedural rules on the supervisory mechanism for the use of force, safeguards for the independence of the Fundamental Rights Officer, an updated Fundamental Rights Strategy and the recruitment of at least 40 Fundamental Rights Monitors, which was due in December 2020. ${ }^{117}$ Furthermore, there was a clear need to improve the reporting mechanisms to ensure the involvement of the Fundamental Rights Officer in the handling of serious incident reports, to guarantee the confidentiality of whistle blowers and to establish a due diligence procedure for the application of Article 46. ${ }^{118}$ The Parliament endorsed the analysis and recommendations of the EU Ombudsman on the complaints mechanism, which should be made much more accessible and safe (meaning no fear for repercussions) for victims of violations. The EU Ombudsman also urged to ensure a follow-up from the Member States and the possibility of sanctions if they are reluctant to cooperate. ${ }^{119}$ The EU Ombudsman didn't problematize that the executive director decides on the merits of a complaint, which questions the level of impartiality and thus, compliance with the right to good administration. ${ }^{120}$

But besides the absence of the necessary rules, it was also the conduct and culture that seemed to prevent a fundamental rights approach. One of the most striking findings was that the Frontex executive director hadn't responded towards any reported concern, recommendation or advice from the Fundamental Rights Officer, despite a clear legal obligation. ${ }^{121}$ It also turned out that reports from external sources evidencing fundamental rights violations were disregarded. More generally, the fundamental rights situation in the Member States is not included in the risk analyses, vulnerability assessments or situational picture. Examinations of serious incidents reports regarding violations by host Member States, are often closed if that state simply denies the allegations or fails to respond. In one of the hearings during the inquiry, the chair of the Management Board stated that not involving other sources to verify an allegation follows from the mutual trust and collegiality underpinning the cooperation with a host Member State. If the basis for a joint operation lacks information about alleged violations, if reports from outside and

\footnotetext{
117 Articles 55(5)(a), 109(4), 8O(1), 110(4) Regulation 2019/1896. See also the letter of DG Pariat to the Chair of the FSWG, "Explanatory timelines for the development of the implementing framework for European Border and Coast Guard Regulation”, 25 May 2021 and European Ombudsman (n 114).

118 One case was found, in which a serious incident about a pushback was 'recategorised' and thus taken away from the Fundamental Rights Officer.

119 European Ombudsman (n 114).

120 This was criticised by Carrera and Stefan (n ...) para 12.3.2.2.

121 Article 109(3)(e) Regulation 2019/1896.
} 
inside are disregarded and if the Agency accepts that host Member States fail to cooperate in a follow up to a serious incident report, it is not surprising that Frontex doesn't see any reason to reconsider its operations. The Agency has only used Article 46 once, with the suspension of its operation in Hungary on 26 January 2021. This was after five years of pressure by the Fundamental Rights Officer and several judgments of the ECtHR and CJEU, and at a moment that Frontex' fundamental rights compliance was under scrutiny. ${ }^{122}$ Yet, only months after that decision, the advisory body Consultative Forum discovered that the return-related operation still continued, despite these returns violating the EU asylum acquis. ${ }^{123}$

\subsection{Joint Operations: Monitoring under Authorization?}

A joint operation is based on an operational plan, which is drafted by the Agency and is binding upon all participants in the operation, covering all aspects of the cooperation including the division of powers and competences, reporting of serious incidents and other safeguards, instructions, and mechanisms for the protection of fundamental rights. ${ }^{124}$ As Frontex is dependent on access to information and certain locations for fulfilling its task to monitor fundamental rights compliance and investigating serious incidents reports and complaints, the FSWG recommended that the operational plan includes clear conditions for this access, with the possibility of sanctions in case of obstruction. ${ }^{125}$ Such conditions could mitigate the effect of the Agency working under the instruction of the host Member State. In the cases brought up by the Bellingcat report, the Greek authorities ordered the Frontex team to leave a place where it had handed over intercepted migrants to the Hellenic coastguard. Sometimes they were even told not to approach certain parts of the operational area. Obeying the Hellenic coastguard, even in case of a reason to suspect that fundamental rights violations were taking place in those areas, would imply that Frontex cannot fulfil its fundamental rights obligations. In my view, Frontex should give priority to comply with its legal obligation in those cases. Obstruction by a host Member State in ensuring proper monitoring by Frontex should also be taken into account while considering Article 46 EUCG, as it could mean that not all information on compliance with fundamental rights is made available. Another element that can hamper Frontex'

122 https://uk.news.yahoo.com/frontex-suspends-operations-hungary-following-200435654 .html. The direct reason was the judgment in case C-808/18 Commission v Hungary, EU:C: 2020:1029.

123 FSWG (n 112).

124 Article 38 Regulation 2019/1896.

125 FSWG (n 112) para 3 A. 
monitoring tasks is that its examination of fundamental rights compliance, for instance in the context of a serious incidents report, is limited to assets financed or co-financed by Frontex. This limitation can trigger a practice in a host Member State to circumvent monitoring within the operational area of a joint operation, simply by financing its own asset. As this limitation lacks a legal basis, the Management Board recommended that host Member States involve all assets used in the operational area, with the objective that every incident in the operational area is reported and properly followed up. ${ }^{126}$

\section{5}

\section{Conclusion: Fundamental Rights and Border Control on Equal Footing?}

This overview shows that the policies and practices on border controls tend to prioritise the prevention of irregular migration at the cost of respect for fundamental rights. As this can be identified at both the EU and national levels, there is no effective correction mechanism equalising both objectives and obligations. It is not a matter of a lack of rules: the fundamental rights are clearly defined, although they could be made more operational in guidelines for border guards, for instance in the Schengen Handbook. The failing interest in monitoring compliance and enforcing fundamental rights obligations is best shown by the absence of criteria in the Schengen Evaluation and Monitoring Mechanism. And this is mirrored by the lack of effective monitoring mechanisms or procedures to investigate complaints in a number of Member States. But also outside the Schengen framework, the Commission has a duty to enforce compliance with the right to access to an asylum procedure, the right to human dignity and liberty and the prohibition of non-refoulement and collective expulsions. The current inaction of the Commission to combat violations and end Member State impunity exacerbates the vulnerability of asylum seekers at the borders.

But the attention to fundamental rights compliance is catching up under the influence of credible reports from authoritative institutions, organisations and journalists about violations at the border. In most cases, the testimonies, reconstructions and documentation are still found insufficient evidence by

126 Frontex, 'Conclusions of the Management Board's meeting on 20-21 January 2021 on the preliminary report of its Working Group on Fundamental Rights and Legal Operational Aspects of Operations in the Aegean Sea' <https://frontex.europa.eu/media-centre/ news/news-release/conclusions-of-the-frontex-management-board-s-meeting-of -20-21-january-2021-LUNC21> accessed ${ }_{15}$ October 2021. 
the authorities, who can afford to deny allegations without substantiation. In a multimedia time, where everything can be livestreamed and followed, the struggle on evidence about alleged violations still continues. The quest for independent monitoring systems is therefore understandable, but will not solve the compliance gaps if enforcement measures remain absent. Access to justice through independent complaint mechanisms is important, but insufficient if the violations are integral part of border policies. The most vital missing element to combat fundamental rights violations is political will. From the Commission to act upon violations at the border, from Member States to address this problem in the Council or bilaterally. As both institutions together form the Management Board of Frontex, fundamental changes within the Agency may not be expected as well. Maybe this impunity will be addressed in the wider context of the rule of law, where Member States are realising that upholding our rights and values is crucial for the functioning of the EU. Maybe. 